\title{
Tidal Energy Potential in the Center Zone of the Colombian Pacific Coast
}

\section{Potencial de energía mareomotriz en la zona central de la costa del Pacífico colombiano}

\author{
DOI: http://doi.org/10.17981/ingecuc.17.2.2021.07
}

Artículo de Investigación Científica. Fecha de Recepción: 09/10/2020. Fecha de Aceptación: 07/11/2020

\author{
Gabriel Esteban Quintero Aguilar \\ Universidad Militar Nueva Granada. Bogotá, D.C. (Colombia) \\ u1102603@unimilitar.edu.co \\ Juan Gabriel Rueda Bayona (D) \\ Universidad Militar Nueva Granada. Bogotá, D.C. (Colombia) \\ juan.rueda@unimilitar.edu.co
}

To cite this article:

G. Quintero Aguilar \& J. Rueda Bayona, "Tidal Energy Potential in the Center Zone of the Colombian Pacific Coast", INGE CUC, vol. 17, no. 2, pp. 65-75. DOI: http://doi.org/10.17981/ingecuc.17.2.2021.07

\section{Resumen}

Introducción- La energía de las mareas está evidenciando un interés a nivel mundial porque se puede estimar con precisión debido al comportamiento cíclico de las mareas. Esta energía puede extraerse de las y turbinas de un embalse (planta de energía mareomotriz), o extraerse de las corrientes de marea a través de una red de microturbinas reversibles de eje horizontal como se propone en este estudio. Así, la región del Pacífico colombiano tiene la oportunidad de implementar microturbinas en áreas estratégicas con el desafío de optimizarlas para extraer energía con alturas de marea locales de hasta $4 \mathrm{~m}$ y velocidades de corriente de hasta $1.5 \mathrm{~m} / \mathrm{s}$.

Objetivo-Calcular los potenciales energéticos de las corrientes de marea en la zona central de la costa pacífica colombiana obtenidos mediant modelado hidrodinámico (Delft3D) validado con información in situ.

Metodología - El presente estudio parte del nivel 1 de desarrollo tecnológico (Niveles de desarrollo tecnológico, TRL en inglés) hasta llegar a TRL 2. Luego, la investigación realizó una revisión documental de experiencias nacionales e internacionales relacionadas con la energía mareomotriz, evidenciando la gran oportunidad que tiene Colombia para aprovechar este tipo de energía y sumarnos al creciente interés internacional por el desarrollo de energías limpias y renovables. Además, este estudio caracterizó las alturas de las mareas y realizó cálculos de potenciales ener éticos a partir de corientes de marea en el Paćfico colombrá pot D) validados con datos medido in situ. Los resultados de este estudio incentivan la aplicación de estas tecnologías en Colombia y representan un aporte al cumplimiento de los Objetivos de Desarrollo Sostenible de la ONU (Energía asequible y no contaminante, ODS 7).

Resultados-De los 4 puntos de análisis, el punto B (Buenaventura) registró el mayor potencial acumulado de generación eléctrica por mes (31546.56 Wh/mes). Las alturas máximas de marea en los puntos A $\mathrm{B}, \mathrm{C}$ y D durante 2018 fueron de $1.88 \mathrm{~m}$. Además, el rango de velocidad media en los puntos A, B, C y D fue de $0.28 \mathrm{~m} / \mathrm{s}$ a $0.54 \mathrm{~m} / \mathrm{s}$, y la velocidad máxima para estos puntos fue de $0.54 \mathrm{~m} / \mathrm{s}, 0.49 \mathrm{~m} / \mathrm{s}, 0.31 \mathrm{~m} / \mathrm{s}$ y $0.28 \mathrm{~m} / \mathrm{s}$ respectivamente. Luego, mediante 5 microturbinas mareales con eje horizontal reversible de $1 \mathrm{~m}$ de área de barrido para el punto de mayor potencial (B), es posible generar energía eléctrica para cubrir el consumo eléctrico de una casa, y con 544 microturbinas el consumo de 99 casas. La granja de mareas (544 microturbinas) requeriría un área de $2079.36 \mathrm{~m}^{2}$ (por ejemplo, $45.6 \mathrm{~m} \times 45.6 \mathrm{~m}$ ) y una profundidad media de $5 \mathrm{~m}$; estos requisitos son factibles de cumplir debido a las características del área de estudio.

Conclusiones- Esta investigación determinó el potencial energético de las mareas en la zona central del Pacífico colombiano para 4 puntos de interés, (A, B, C y D) y los mayores potenciales se encontraron en los puntos A y B ubicados en Bahía Málaga y Buenaventura respectivamente. Además, se analizaron las velocidades mínimas, la duración de estas y el régimen de mareas diurno ( $12 \mathrm{~h}$ ), y se encontró que los puntos A y $\mathrm{B}$ mostraron los tiempos más bajos (1 h y $2 \mathrm{~h}$ ) de velocidad mínima, evidenciando una capacidad tivamente. En consideración a los resultados obtenidos, esta investigación muestra la oportunidad de realizar estudios para promover el desarrollo de microturbinas reversibles de eje horizontal para el aprovechamiento de la energía mareomotriz. La energía generada podría ser suministrada a comunidades con dificultades de acceso a la red de distribución eléctrica, lo que reduciría la pobreza y la emisión de Gases de Efecto Invernadero GEI) por la quema de combustibles fósiles y vegetales (leña).

Palabras clave - Energía renovable; energía de las mareas; Delft3D; potencial energético; modelado hidrodinámico, microturbinas

\section{Abstract}

Introduction - Tidal energy is evidencing interest worldwide because it can be accurately estimated due to the cyclical behavio of the tides. This energy can be extracted from differences in sea level height through the use of gates and turbines of a reservoir (tidal power plant), or extracted from tidal currents through grid of reversible horizontal axis microturbines as proposed in this grid of reversible horizontal axis microturbines as proposed in this
study. Thus, the Colombian Pacific region has the opportunity to study. Thus, the Colombian Pacific region has the opportunity to implement microturbines in strategic areas with the challenge of $\mathrm{m}$ and current velocities up to $1.5 \mathrm{~m} / \mathrm{s}$.

Objective- Calculate the energy potentials from tidal current in the central zone of the Colombian Pacific coast obtained through hydrodynamic modeling (Delft3D) validated it with in situ information

Methodology-The present study starts from level 1 of technological development (Technology Readiness Levels, TRL) till reaching the TRL 2 . Then, the research performed a documentary review of national and international experiences related to tidal energy, evidencing the great opportunity that Colombia has to take advantage of this type of energy and join to the growing international interest in the development of clean and renewable energies. In addition, this study characterized the tidal heights and did calculations of energy with measured in situ data. The results of this study encourage the application of these technologies in Colombia and represents a contribution to the fulfillment of the UN sustainable development objectives (Affordable and non-polluting energy, SDG 7).

Results - From the 4 analysis points, the point B (Buenaventura) registered the highest accumulated potential for electricity generation per month ( $31546.56 \mathrm{Wh} / \mathrm{month}$ ). The maximum tidal height at points A, B, C and D during 2018 were $1.88 \mathrm{~m}$. Furthermore, the mean velocity range at points $A, B, C$ and $D$ was $0.28 \mathrm{~m} / \mathrm{s}$ to $0.54 \mathrm{~m} / \mathrm{s}$, and the maximum velocity for these points were $0.54 \mathrm{~m} / \mathrm{s}$, $0.49 \mathrm{~m} / \mathrm{s}, 0.31 \mathrm{~m} / \mathrm{s}$ and $0.28 \mathrm{~m} / \mathrm{s}$ respectively. Then, by means of 5 tidal microturbines with a reversible horizontal axis of $1 \mathrm{~m}$ sweep area for the point of highest potential (B), it is possible to generate electrical energy to meet the electrical consumption of a house, and with 544 microturbines the consumption of 99 houses. The tidal farm (544 microturbines) would require an area of $2079.36 \mathrm{~m}^{2}$ (e.g. $45.6 \mathrm{~m} \times 45.6 \mathrm{~m}$ ) and an average depth of $5 \mathrm{~m}$; these requirement are feasible to be met because of the study area characteristics.

Conclusions-This research determined the tidal energy potential in the central zone of the Colombian Pacific for 4 points of interest $(\mathrm{A}, \mathrm{B}, \mathrm{C}$ and $\mathrm{D})$ and the highest potentials were found in points $\mathrm{A}$ and B located in Bahía Málaga and Buenaventura respectively. In addition, the minimum velocities, the duration of these and the diurnal tidal regime (12 h) were analyzed, and it was found that points $\mathrm{A}$ and $\mathrm{B}$ showed the lowest times $(1 \mathrm{~h}$ and $2 \mathrm{~h}$ ) of minimum velocity, respectively. In consideration of the obtained results, this research shows the opportunity to perform studies for promoting the development of reversible horizontal-axis microturbines for the exploitation of tidal energy. The generated energy could be supplied to communities with access difficulties to the electricity distribution network, what would reduce poverty and the emission of Greenhouse Gase (GHG) due to the burning of fossil and plant-based fuels (firewood) Keywords- Renewable energy; tidal energy; Delft3D energy potential; hydrodynamic modeling, microturbines 


\section{INTRODUCTION}

The growing interest in reducing $\mathrm{CO}_{2}$ emissions and mitigating the impacts of climate change due to global warming has motivated several countries to meet the targets set in the Sustainable Development Goals (SDGs) of the United Nations [1]. Besides, initiatives such as the Kyoto Protocol have been taken, which assigned goals to developed countries for the reduction of Greenhouse Gas (GHG) emissions by at least 5\% of their annual emissions [2]. Several studies conducted a review of non-conventional renewable energies in Colombia where it reported tidal energy as one of the available sources in the country [3]. University of British Columbia reported that the Paris Agreement is a viable strategy to reduce the carbon footprint to mitigate negative impacts of climate change [4]. In this regard, the massive implementation of renewable energy sources (RES) for electricity generation is an opportunity to comply with international agreements, where the European Union committed to generate $45 \%$ of electricity from RES by 2030 [5].

Within the SDG 7 (Affordable and non-polluting energy), tidal power energy generation is attracting international attention as it stimulates economic growth in coastal and remote areas [6]. Besides, tidal power energy is an abundant renewable resource that is beginning to be used in several countries such as the UK, France, Australia, the United States and China [7].

The development of tidal power generation technology has encountered constraints and obstacles in the_initiatives and projects under development. The implementation of tidal energy is progressing at a slower pace than expected, because the market has not been established yet. For example, the construction of the tidal lagoon in Swansea Bay had limitations that generated delays in its construction because the State decided to cancel the subsidies for presenting high costs. However, participants said that the project would run without government money and its construction would be done in six years. Also, private companies such as Land Securities Real Estate, Cardiff Airport and developer Berkeley Group signed agreements to buy lowcarbon electricity to protect against future energy price increments, and for improving green credentials by purchasing from renewable sources [8].

In Europe, the member states of the National Renewable Energy Plan (PANER) set a target for tidal power generation capacity to reach 2,250 MW per year or about $0.5 \%$ of the total of installed electricity capacity in the EU by 2020 . The industry aims to install $100 \mathrm{GW}$ tidal power capacity by 2050 [9], where currently there are $0.5 \mathrm{GW}$ of commercial marine power generation capacity working and $1.7 \mathrm{GW}$ under construction, where $99 \%$ corresponds to tidal energy by harnessing the high and low tide: tidal range [6].

Several countries such as Australia, England, France, India, Canada and South Korea have increased their efforts to identify alternative power generation from tidal-regulated reservoirs [10]. In the United Kingdom (UK) implemented satellite altimetry models to analyze the total potential through lagoon systems [10]. The research concluded that $90 \%$ of the world's resources for the tidal range is distributed in 5 countries which are Australia, Canada, UK, France and the USA (Alaska), where Australia represents $30 \%$ of the world's available potential.

Currently, several reservoir-type tidal energy projects are under development and operation, such as Sihwa Lake Tidal Power Station in South Korea (254 MW), La Rance Tidal Power Plant, France (240 MW), Swansea Bay Tidal Lagoon, Gales (240 MW), Annapolis Royal Generating Station, Canada (20 MW), where tidal heights exceed 8 m. The MeyGen Tidal Energy Project in Scotland (86 MW) is one of the first using an offshore turbine grid without dams, which expects to reach its total installed capacity of $398 \mathrm{MW}$ by 2020 . Therefore, it can be seen that in tidal power generation technology, dams projects predominate in study areas with tidal heights of more than $8 \mathrm{~m}$.

Colombia in particular generates $70 \%$ of its electricity through hydroelectric plants. However, interest in developing projects for electricity generation from renewable energies in Colombia has been increasing due to its high potential. In 2019 an analysis of the potential and current situation of electricity generation from non-conventional renewable energies (NCRE) was presented [11]. The study presented 3 scenarios and does a comparison with the forecast for 2020 made by the Energy Mining Planning Unit (UPME) where it is evident that Colombia has a great potential to increase the installed capacity through NCER. 
Pontificia Universidad Javeriana (Colombia) presented the energy potentials of tidal currents along the Colombian Pacific coast [12]. The researchers used bathymetric databases such as ETOPO and Landsat images combined with in situ bathymetries carried out by the Colombian Maritime General Directorate (DIMAR, in Spanish). The research showed 45 possible bays in which the estimated energy potential is $120000 \mathrm{~kW}$. However, this research did not indicate whether the potential is monthly or daily, in addition, they didn't specify that the calculated energy power is the power density for the total area of the study, what isn't practical for the formulation of future energy projects.

Universities in Japan used a high-resolution model to assess the tidal current energy potential at Kuroshio [13]. The researchers performed two experiments to characterize the Kuroshio large meander, calculating the current average velocity and current vector stability with ADCP (Acoustic Doppler Current Profiler) measurements. They indicated three scenarios in which it is appropriate to implement the experiment: around the Tokara Strait. Other UK universities implemented two regional hydrodynamic models of the Pentland Firth and Orkney waters using computational tools (MIKE 3 and Delft3D) in order to identify the accuracy of these software to predict the effects of tidal energy [14]. The researchers modeled realistic scenarios for energy extraction in each of the software and compared their predictions. The research concluded that the implemented models were suitable for a large-scale assessment of the effects of energy extraction.

Several studies have estimated that $25 \%$ of tidal energy in Europe is in Scottish waters and the potential to generate electricity is greater than what is currently consumed [15]. The University of Edinburgh (UK) provided a detailed analysis of several input parameters of two different numerical models: Telemac3D and Delft3D which are used for the simulation of tidal current flow at potential tidal energy sites in the Pentland Firth in Scotland [16]. The research results indicated that the Telemac3D and Delft3D models allowed an excellent comparison with the measured data, where Delft3D the model showed the highest correlation compared to the measured data.

According to the literature review, it was observed that in Colombia only two studies of tidal energy have been performed, where calculations of the tidal power available according to the turbine sweep area has not been made, the provided information of these studies corresponds to power densities which are an approximation of the usable energy per square meter. Moreover, no details of calibrated hydrodynamic modeling for the central Colombian Pacific were presented, nor engineering details and recommendations for the implementation of a tidal farm were shown. Also, it is estimated that $20 \%$ of the houses located in the Colombian Pacific coast belong to Not Interconnected Zones (ZNI) to the electricity network, so they are driven to seek energy through isolated solutions with fossil fuels such as Diesel.

Due to the above, this study is a contribution to improve the understanding of the available tidal energy potential and how it could be harnessed through the development of microturbines with a sweep diameter of $1 \mathrm{~m}$. This research would be the first contribution for Colombia in which potentials are quantified for shallow areas with tidal range below to $4 \mathrm{~m}$, what is considered a challenge for the implementation of tidal energies in the world. In this sense, this research generates knowledge for diversifying the Colombian energy matrix, and the reduction of energy access limitations for those communities without access to the national energy distribution network, with an engineering proposal for improving the socio-economic conditions of vulnerable communities in Buenaventura city.

\section{Methodology}

The study area is located in the central area of the Pacific coast of Colombia [17], where 4 points of interest were defined (Fig. 1) with the following coordinates:

- Point A: $3^{\circ} 57^{\prime} 54,420^{\prime \prime} \mathrm{N}-77^{\circ} 19^{\prime} 11,651^{\prime \prime} \mathrm{W}$

- Point B: $3^{\circ} 45^{\prime} 24,653$ ” N - 77 $17^{\circ}$ ' 0,145” W

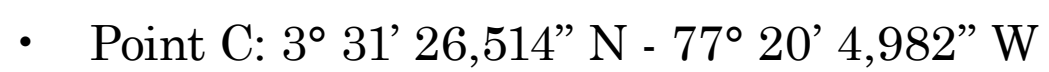

- Point D: $3^{\circ} 18^{\prime} 49,453^{\prime \prime} \mathrm{N}-77^{\circ} 27^{\prime} 2,025^{\prime \prime} \mathrm{W}$ 


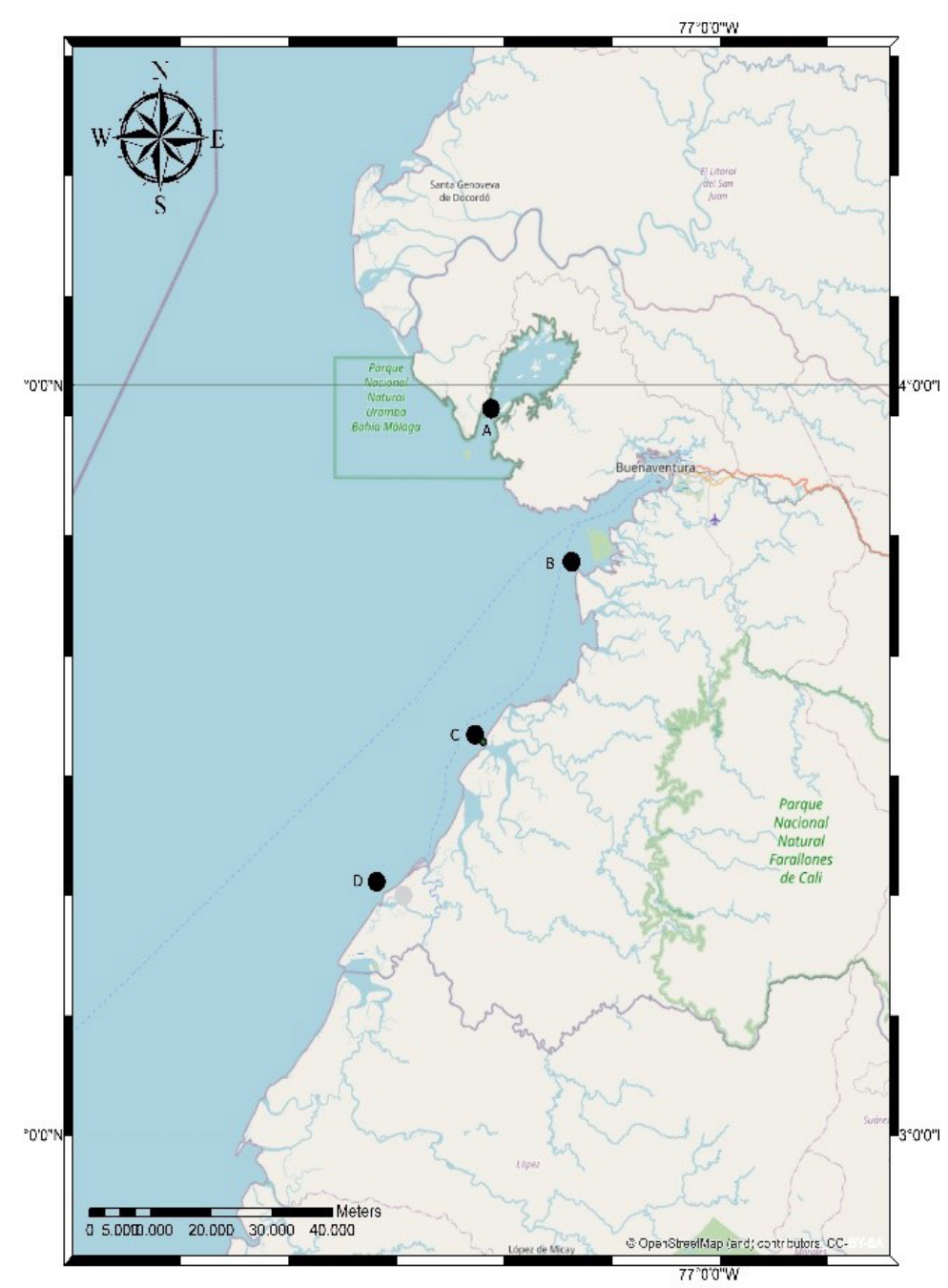

Fig. 1. Geographic location of the study area. Source: Authors.

For the present study, bibliographic databases were used: Elsevier, Scopus, Research Gate, Science Direct, Google academic, Scielo, as well as the official databases of public institutions in Colombia: Ministry of mines and energy (MINMINAS, minenergia.gov.co), the Energy Mining Planning Unit (UPME, upme.gov.co) and the Superintendency of public and residential services. These databases allowed to identify the state of the art in Colombia and to understand the problems in identifying strategic and vulnerable areas in the central Colombian Pacific which require access to clean and renewable energy.

Wind information for the hydrodynamic model was obtained from the NAAR-NOAA Reanalysis database [18]. The wave information to force the hydrodynamic model was obtained from the WAVEWATCH III database [19] and the western boundary of the numerical grid was taken as a boundary condition. Bathymetric information was obtained from the ETOPO 1 database [20], which was validated and supplemented by nautical charts from the Colombian DirectorateGeneral for Maritime Affairs (DIMAR). The software Google Earth and ArcGIS were used for the identification of the coastline required for the delimitation of the hydrodynamic meshes of the Delft3D numerical model. For the validation and calibration of the numerical model, was used in situ data of tides measured by DIMAR in Buenaventura city. Temperature and salinity information for the numerical model was retrieved from the WOCE database [21] validated with in situ information provided by DIMAR.

The month of September 2018 was defined for the calculation of tidal energy potentials considering that this month presents the highest wind records for the region [17]. The maximum wind speeds of September reduce current velocities in ebb tide, which affects the calculation of the available power. As a result, current calculations of tidal energy potentials were made during the less favorable time of the year (September) for power generation.

\section{A. Energy potential estimation}

From the available power equation (1) it is possible to determine the available energy potential from the following expression [22]:

$$
P=\frac{1}{2} * \rho * A * v^{3} * c p
$$


Where:
$\rho=\quad$ Density of seawater in $\mathrm{kg} / \mathrm{m}^{3}$ [23].
$A=\quad$ Turbine sweep area in $\mathrm{m}^{2}$ equal to $1 \mathrm{~m}$ diameter established by the authors.
$v=\quad$ Velocity in $\mathrm{m} / \mathrm{s}$ from hydrodynamic modeling in Delft3D.
$c p=\quad$ Turbine power coefficient.

The study of Universidad Politécnica Metropolitana de Hidalgo [24] was taken as a reference for the selection of the Power Coefficient factor $(C p)$. From the work of Aleem, Zobaa and Ibrahim [25] the value of $C p=0.4$ was defined in consideration of the relationship between the Power Coefficient $(C p)$, also called lambda $(\lambda)$, and a Tip-Steep Ratio (TSR) of 4 . The following is the methodological scheme applied for the research (Fig. 2):

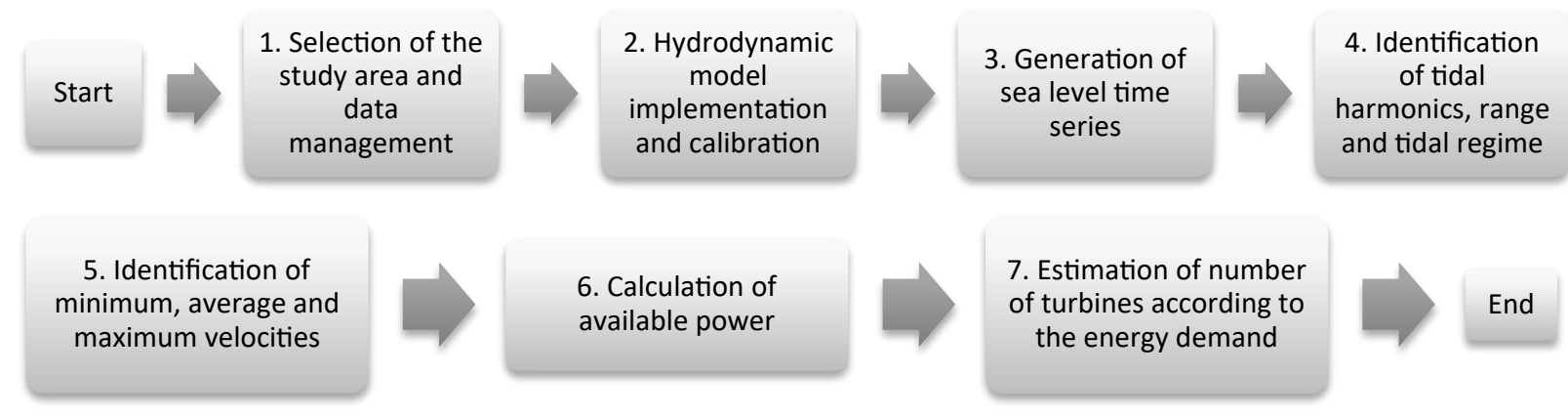

Fig. 2. Methodology for estimating available power for tidal current power generation. Source: Authors.

\section{Results And Discussion}

After identifying the study area, the Delft3D hydrodynamic model was implemented [26]. As a result, the hydrodynamic model was successfully calibrated according to the numerical results of sea level. Therefore, the modeling results were compared with the measured data from October $15^{\text {th }} 2009-7 \mathrm{~h}-$ to October $26^{\text {th }} 2009-20 \mathrm{~h}-$ (Fig. 3), and through a regression analysis was calculated a correlation coefficient $\left(r^{2}\right)$ of 0.97 with $p$-value $<0.005$ for $95 \%$ of confidence. Additionally, it was observed that in some time intervals the model predicted sea level heights below to the measured records $(1 \mathrm{~m})$, what can be considered positive because the model underestimated the measured data, providing a conservative safety factor for the energy potential estimation. Otherwise, an overestimation of the model would increase the risks of estimating potentials above to the expected, leading to increased costs due to the oversized size of the turbines in subsequent study designs.

a)

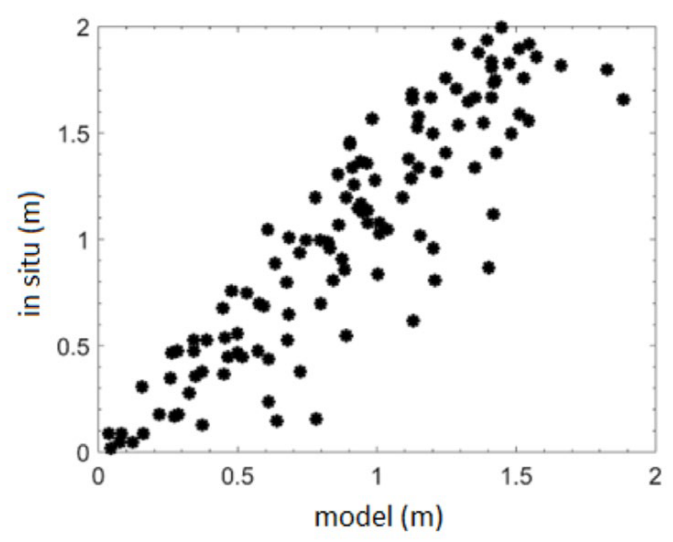

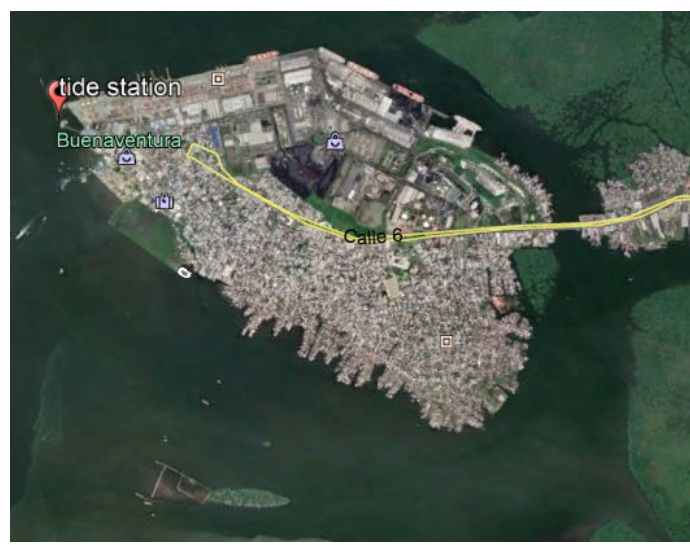

c)

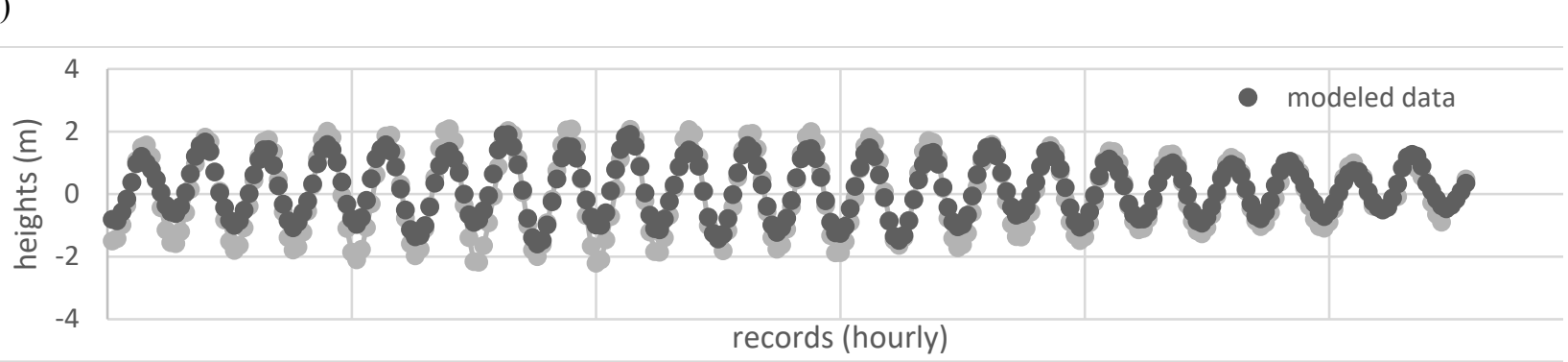

Fig. 3. a) Comparison of sea level data modeled by Delft3D and measured in situ from 07:00 h - 15/10/2009 to 20:00 h - 26/10/2009. b) Location of DIMAR tidal station in Buenaventura city, Colombia ( $3^{\circ} 53^{\prime} 31,2^{\prime \prime} \mathrm{N}$, $\left.-77^{\circ} 4^{\prime} 44,4^{\prime \prime} \mathrm{W}\right)$, used for model calibration. c) Comparison of measured and modeled sea level time series.

Source: Authors. 
After calibrating and validating the hydrodynamic model, a simulation of tidal heights was performed for the four study sites from $1^{\text {st }}$ of January to December 31 of 2018 (Fig. 4). For all 2018 year a similar tidal behavior was found for the 4 study points, where the heights did not exceed $4 \mathrm{~m}$ of elevation. Then, a Fourier Analysis was performed to the sea level results, and the tidal main harmonics are presented in Table 1.

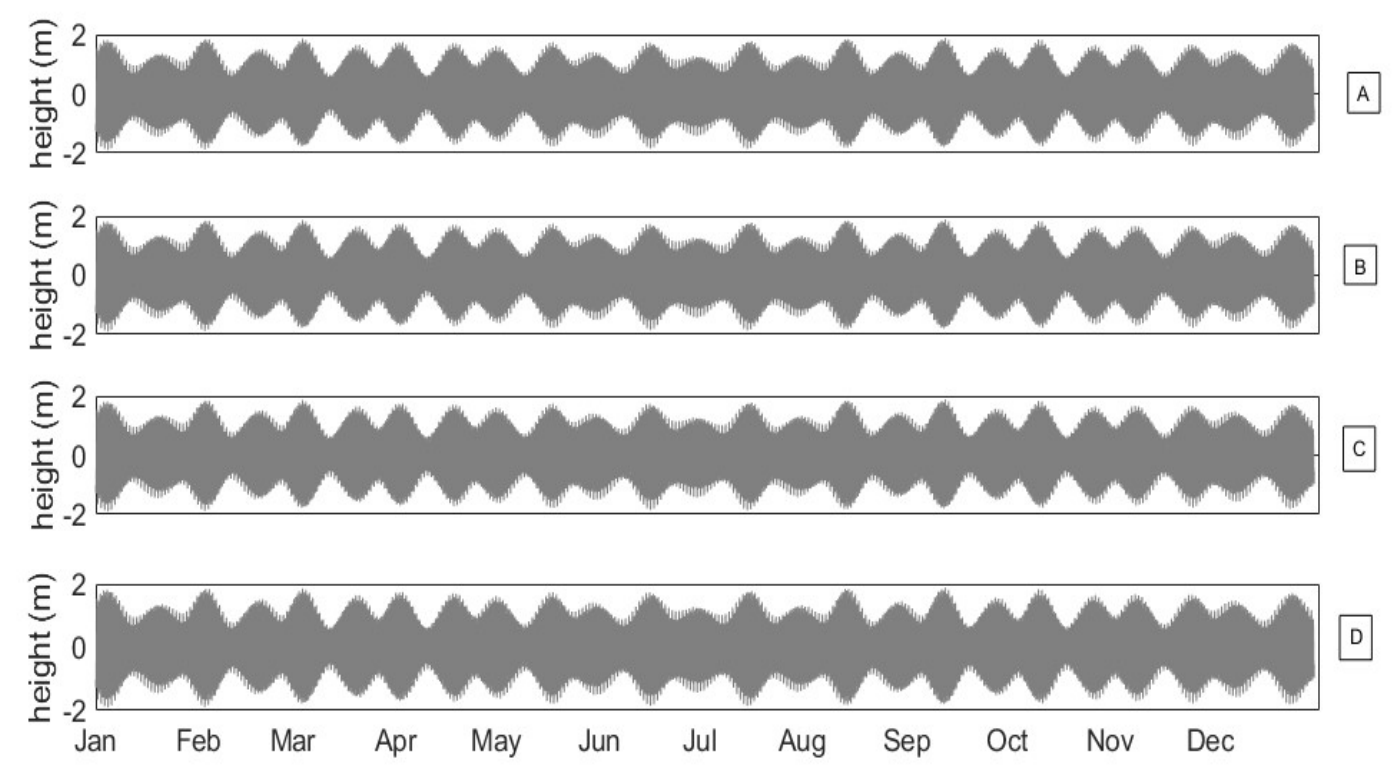

Fig. 4. Modeled tidal heights during September 2018 for points A, B, C and D. Source: Authors.

TABle 1. Tidal COMPonents of POINT A OF THE STUdy AREA.

\begin{tabular}{|l|l|l|l|l|l|}
\hline Harmonic & time $(\mathrm{h})$ & \multicolumn{1}{c|}{ A } & \multicolumn{1}{c|}{ B } & amplitude $(\mathrm{m})$ & \multicolumn{1}{c|}{ Phase $\left(^{\circ}\right)$} \\
\hline M2 & 12.42 & 1.160602 & -0.274392 & 1.192597 & -13.301752 \\
\hline S2 & 12.00 & 0.157237 & -0.294198 & 0.33358 & -61.87736 \\
\hline O1 & 25.80 & -0.027642 & -0.000741 & 0.027652 & -178.464549 \\
\hline K1 & 23.94 & 0.060606 & 0.085448 & 0.104759 & 54.652836 \\
\hline
\end{tabular}

Source: Authors.

From the tidal harmonics of the study area (Table 1), the tidal parameters of the tidal regime were calculated, such as tidal factor (equation 2) where $a$ is amplitude, sea level $\left(\sum a\right)$, the syzygy tidal range $\mathrm{RS}=2.0\left(\mathrm{a}_{\mathrm{M} 2}+\mathrm{a}_{\mathrm{S} 2}\right)$, and quadrature $\mathrm{RC}=2.0\left(\mathrm{a}_{\mathrm{M} 2}-\mathrm{a}_{\mathrm{S} 2}\right)$ according to TU Delft [27]. The results indicated that the study area presents a mixed tide predominantly diurnal $(\mathrm{F}=2.04)$, sea level of $0.0037 \mathrm{~m}, \mathrm{RS}$ of $3.05 \mathrm{~m}$ and $\mathrm{RC}$ of $0.61 \mathrm{~m}$. The previous results showed that the highest sea level heights did not exceed $4 \mathrm{~m}$, where the tide periods allow a tidal current flow in both directions every $12 \mathrm{~h}$. This justifies exploring the use of reversible microtidal turbines that take advantage of the tidal currents of the study area, and not the tidal heights as does the traditional dam-type technology which requires heights greater than $8 \mathrm{~m}$.

$$
\left(F=\frac{a_{K 1}+a_{O 1}}{a_{M 2}+a_{S 2}}\right)
$$

Fig. 5 shows the horizontal velocity behavior derived from the hydrodynamic modeling performed in Delft3D; when analyzing them, it was observed that at points A and B the pointed the highest records of current velocities, what represent the highest energy potentials in the study area.

In order to analyze the velocity variation in time of the 4 points, the Fig. 6 shows the variation of tidal flow velocities for the month of September 2018. As seen in Fig. 6, the points A and $\mathrm{B}$ showed current velocities higher than the points $\mathrm{C}$ and $\mathrm{D}$, modulated by the fortnightly variations (360 h) related to the changes of Sicigy (highest tides) and Quadrature (lowest tides). 
a)

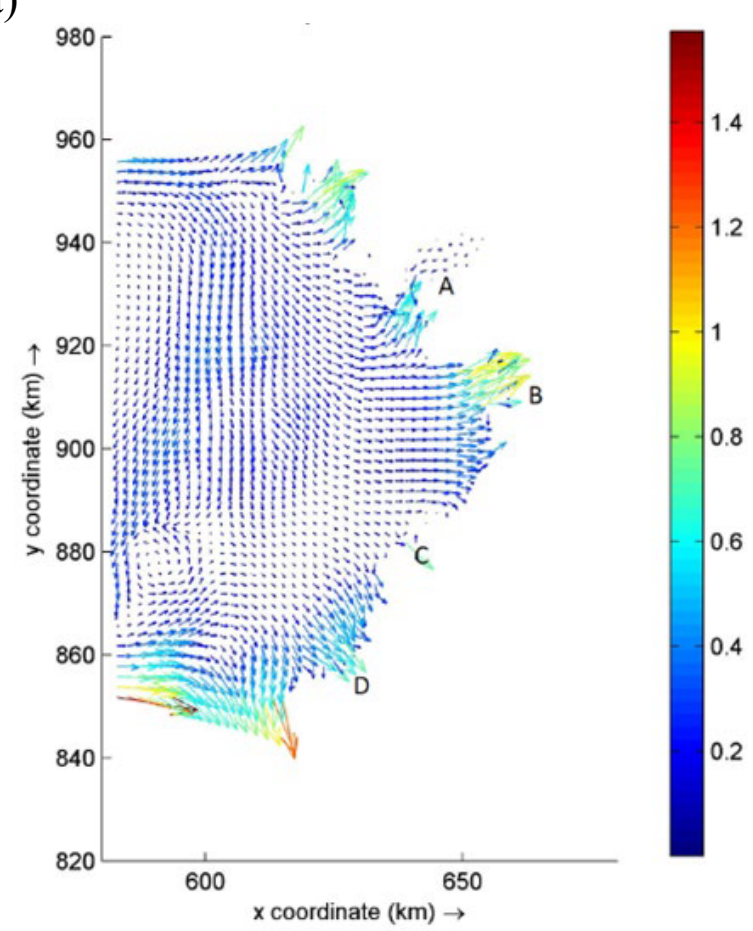

b)

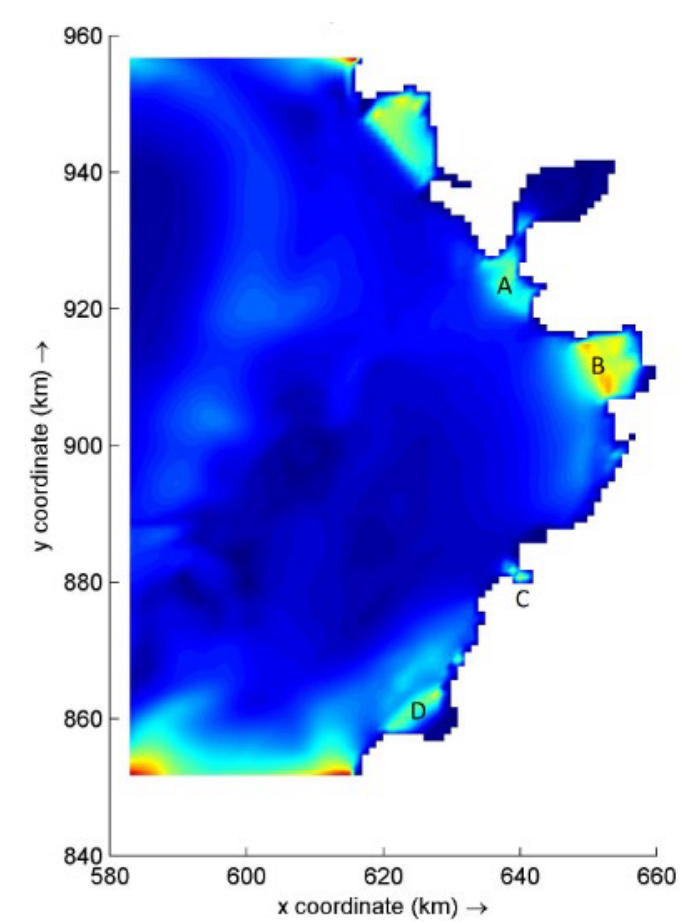

Fig. 5. Instantaneous velocity field (m/s) modeled by Delft3D (September 23 of $2018-22: 00 \mathrm{~h}$ ). Coordinates in Magna Sirgas Bogotá system. Source: Authors.
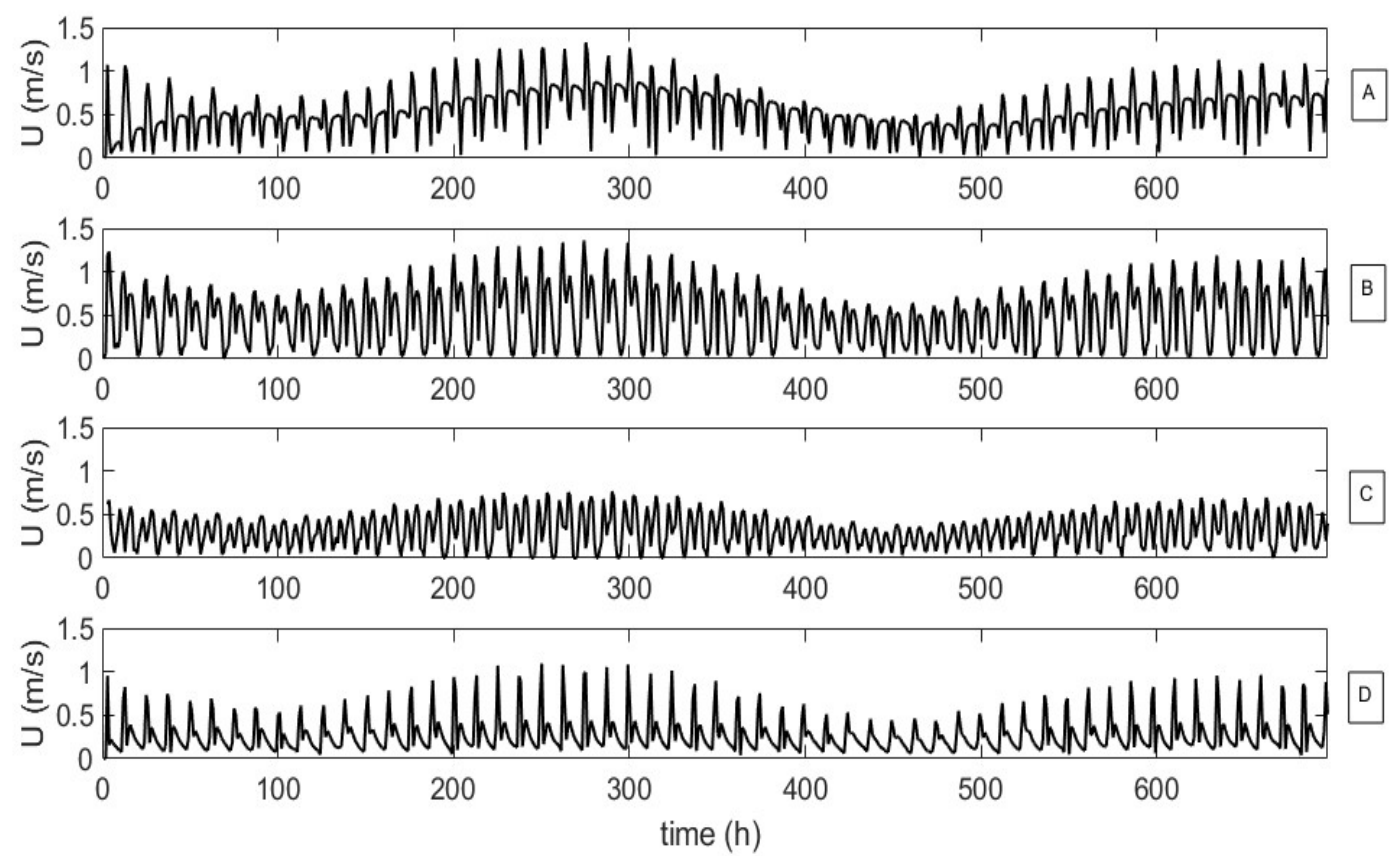

Fig. 6. Modeled tidal current velocities during September 2018 for points A, B, C and D. Source: Authors.

Table 2 shows the representative values of the 4 points, where points A and B doubled the maximum velocity record of $\mathrm{C}$ and exceeded the record of point $\mathrm{D}$. The average velocities at the 4 points were between $0.54 \mathrm{~m} / \mathrm{s}$ and $0.28 \mathrm{~m} / \mathrm{s}$ and the average and maximum height at all points were $0.78 \mathrm{~m}$ and $1.88 \mathrm{~m}$ respectively.

Table 2. Characteristic tidal velocities and heights of the 4 POINTS for SePtember 2018.

\begin{tabular}{|l|l|l|l|l|}
\hline point & $\begin{array}{c}\text { Maximum } \\
\text { velocity }(\mathrm{m} / \mathrm{s})\end{array}$ & $\begin{array}{c}\text { Average } \\
\text { velocity }(\mathrm{m} / \mathrm{s})\end{array}$ & $\begin{array}{c}\text { Maximum } \\
\text { height }(\mathrm{m})\end{array}$ & $\begin{array}{c}\text { Average } \\
\text { height }(\mathrm{m})\end{array}$ \\
\hline A & 1.33 & 0.54 & 1.88 & 0.78 \\
\hline B & 1.36 & 0.49 & 1.88 & 0.79 \\
\hline C & 0.77 & 0.31 & 1.88 & 0.78 \\
\hline D & 1.09 & 0.28 & 1.88 & 0.78 \\
\hline
\end{tabular}

Source: Authors.

In order to determine which velocities would be associated with periods of minimal energy production of turbines, and how long this period would last (dead time) the Fig. 7 was generated. 
The results of the minimum velocities indicated that at maximum velocity points of $\mathrm{A}$ and $\mathrm{B}$, the idle time was $1 \mathrm{~h}$ and $2 \mathrm{~h}$ respectively, and at points $\mathrm{C}$ and $\mathrm{D}$ the idle time was $3 \mathrm{~h}$ and 4 $h$ respectively. As a result, points $A$ and $B$, showed the lowest duration of minimum velocity, positioning them as the most appropriate zones for the use of micro tidal turbines.
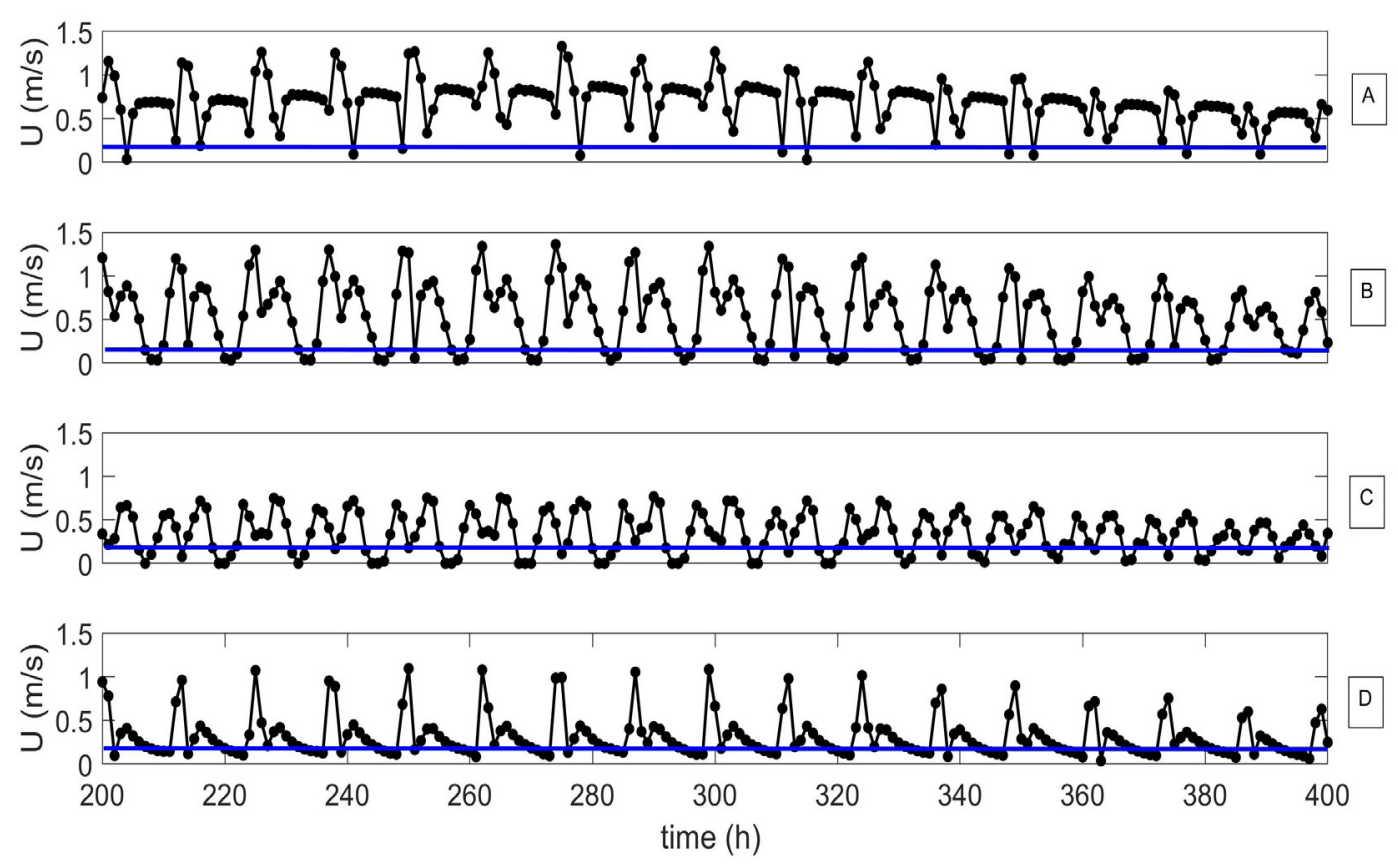

Fig. 7. Minimum tidal current velocity during September 2018 for points A, B, C and D. Source: Authors.

After identifying the minimum velocities of the points of interest, the tidal power was determined through (equation 1) as shown in Fig. 8.

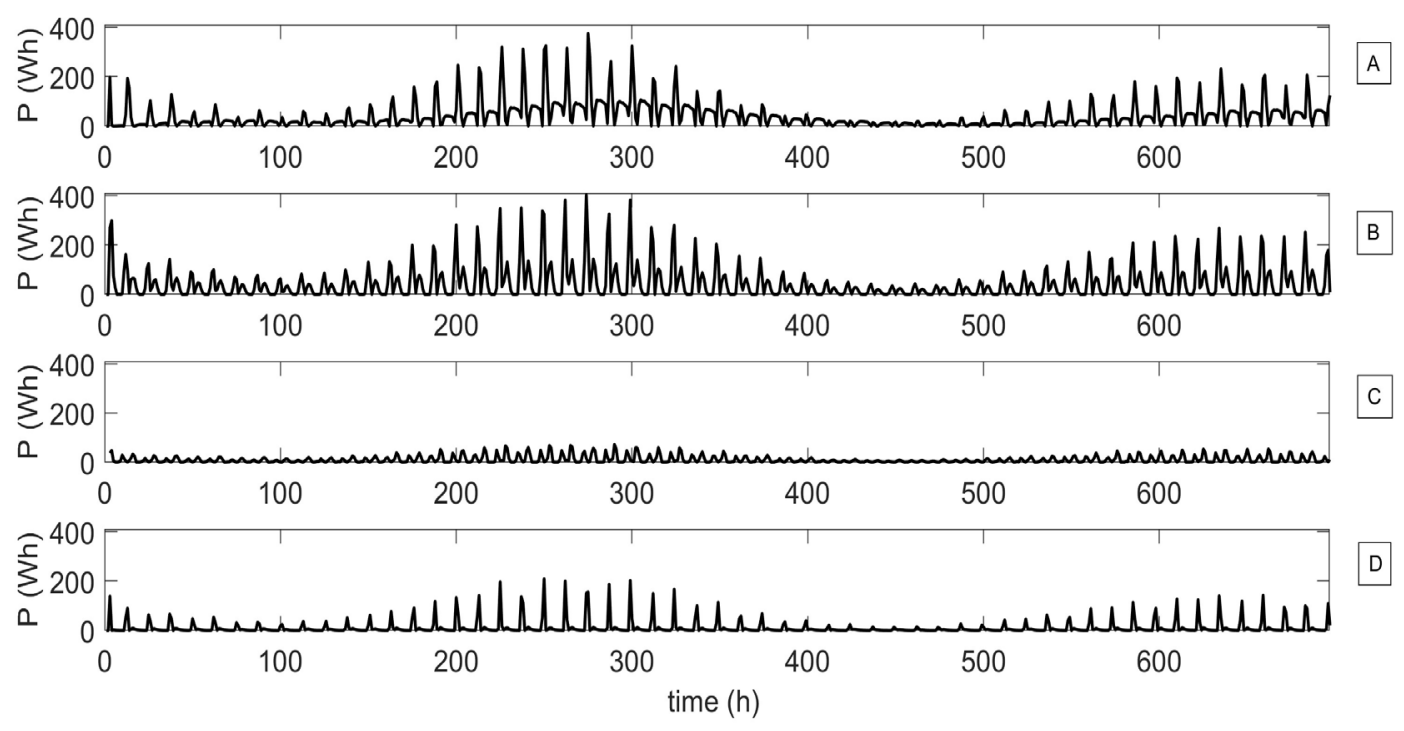

Fig. 8. Available tidal power for September 2018 for points A, B, C and D. Source: Authors.

Table 3 list the results of available tidal energy potential, where points A and B showed the highest potential for power generation. Thus, the highest potential for tidal energy in the central Colombian Pacific was 19360 considering a $1 \mathrm{~m}$ diameter (sweep area) tidal microturbine.

TABle 3. AVAilable EnERgy Potential For the STUdy AREA GENERATED BY A TIDAL TURBINE WITH 1 M OF SWEEP AREA DURING SEPTEMBER 2018.

\begin{tabular}{|l|l|l|}
\hline point & \multicolumn{1}{|c|}{$\begin{array}{c}\text { Maximum } \\
\text { potential Wh }\end{array}$} & $\begin{array}{c}\text { Accumulated potential } \\
\text { per Month Wh/month }\end{array}$ \\
\hline A & 375.44 & 30185.75 \\
\hline B & 402.79 & 31546.56 \\
\hline C & 71.90 & 7363.13 \\
\hline D & 209.20 & 8348.18 \\
\hline
\end{tabular}

Source: Authors. 
For estimating the number of tidal microturbines that can satisfy the energy consumption of a sector of the city of Buenaventura (Fig. 1, point B), was analyzed the electricity consumption per house (data provided by the energy company CELSIA), where the consumption per municipality in places located at $1000 \mathrm{~m}$ of elevation is $173 \mathrm{kWh} / \mathrm{month}$. Consequently, Table 4 reports the number of microturbines needed to satisfy the electricity demand of the San José neighborhood located in the Cascajal's island (Buenaventura city). The neighborhood is integrated by 99 houses, place recognized as the the most forgotten and poor neighborhoods of the city where the connection to the electricity service is made fraudulently.

TABle 4. Estimation of THE NUMber of Microturbines (1 M DiAMETER OF SWEEP AREA) TO SUPPLY THE ENERGY CONSUmption of THE SAN José neighborhood (99 houses) in BuEnaventura.

\begin{tabular}{|l|l|l|l|}
\hline $\begin{array}{c}\text { House } \\
\text { number }(\mathrm{hn})\end{array}$ & $\begin{array}{c}\text { Accumulated energy consumption } \\
\text { Wh/mes per houses }(\mathrm{hn})\end{array}$ & $\begin{array}{l}\text { Number of microturbines } \\
(\mathrm{nm}) \text { required per house }\end{array}$ & $\begin{array}{c}\text { Tidal generation potential Wh/ } \\
\text { month per nm microturbines }\end{array}$ \\
\hline 1 & 173000 & 6 & 189279 \\
\hline 99 & 17127000 & 544 & 17161296 \\
\hline
\end{tabular}

Source: Authors.

Based on the results of Table 4, it was evidenced that supplying the energy consumption of the San José neighborhood requires a tidal farm of 544 microturbines within an area of $2079.36 \mathrm{~m}^{2}$ (e.g $\left.45.6 \mathrm{~m} \times 45.6 \mathrm{~m}\right)$ with a minimum depth of $5 \mathrm{~m}$. Finally, the tidal farm for the city of Buenaventura would be located geographically at coordinates $3^{\circ} 53^{\prime} 2.78^{\prime \prime} \mathrm{N}$ and $77^{\circ} 4^{\prime} 36.21^{\prime} \mathrm{W}$, and it would have an arrangement of $16 \times 34$ microturbines separated among them by $1 \mathrm{~m}$ of distance, and located at a distance to the coast not higher than $50 \mathrm{~m}$ (Fig. 9).

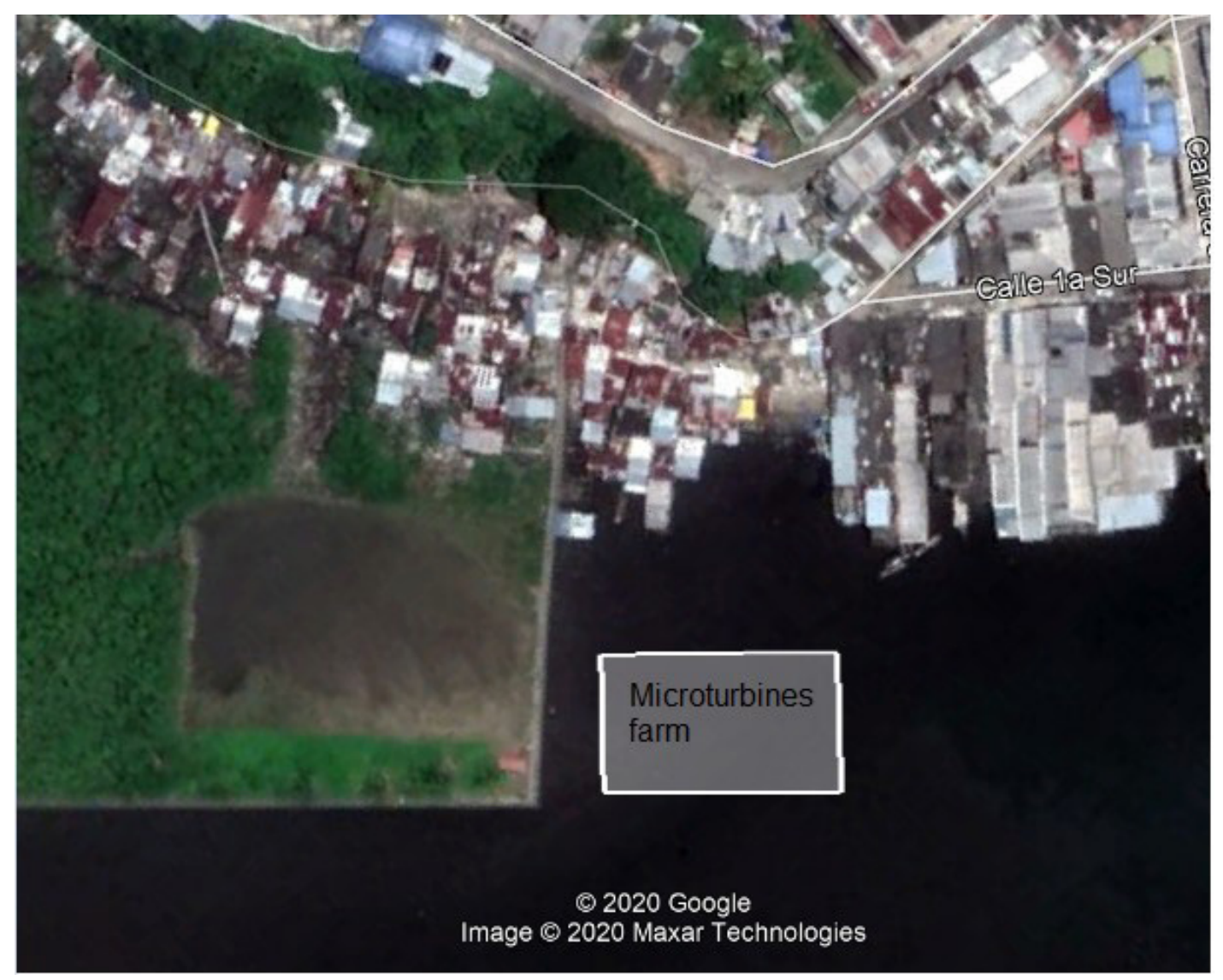

Fig. 9. Location of the microturbine farm to supply the energy consumption of the San José neighborhood of Buenaventura city.

Source: Google.

\section{Conclusions}

Through the implementation and calibration of a hydrodynamic model, the available tidal energy potentials for 4 points of interest in the central Colombian Pacific were identified. The month of September was chosen for the analyses because during that period the maximum surface winds appear and reduce the current velocities during ebb tides. In this sense, the analyzed month allows a higher degree of reliability for power generation during adverse conditions. 
It was found that the analyzed point located in Buenaventura city (Point B) showed the highest accumulated available energy potential. In addition, the results of minimum velocities, duration time and diurnal tidal regime $(12 \mathrm{~h})$, indicated that points A and B presented the lowest minimum velocity times $(1 \mathrm{~h}$ and $2 \mathrm{~h}$ ), allowing a daily power generation capacity of $22 \mathrm{~h}$ and $20 \mathrm{~h}$ respectively. As a result, point B was selected and calculations were made to supply the energy consumption of the San José neighborhood located in Buenaventura city. The calculations indicated that it is possible to meet the local energy demand with 544 microturbines distributed in $2079.36 \mathrm{~m}^{2}$, at a distance to the coast not higher than $50 \mathrm{~m}$.

The results of this research are considered at the level of pre-feasibility, which are a contribution to the development of new projects for the application of non-conventional renewable energy technologies in Colombia, which represents a contribution to the achievement of the Sustainable Development Goals of the United Nations, specifically Goal 7: Affordable and clean energy. After pre-feasibility studies such as the present research, complementary studies should be done to reach higher levels of technological development (TRL 9), such as the construction and evaluation of pilot plants. In consideration of the results of this research, Colombia has the opportunity to continue advancing in the development of tidal technology through reversible microturbines for tidal heights below $4 \mathrm{~m}$ and velocities up to $1.5 \mathrm{~m} / \mathrm{s}$, being this a progress in the development of power generation technologies worldwide, in which damtype plants currently predominate.

For future research it is recommended to perform an hourly energy consumption study to identify the maximum and minimum hours of consumption of the district or city under study, in order to analyze and propose a project for the generation of energy considering the population energy consumption peaks and tidal energy peaks. Due to the generation capacity of tidal micro-turbines would change daily depending on the tidal cycle, is required an accurate estimation considering the balance between the energy supply and the demand.

\section{ACKNOWLEDGEMENTS}

This project was funded by the Universidad Militar Nueva Granada through the research project INV-ING-3196.

\section{REFERENCES}

[1] ONU, "Objetivos de Desarrollo del Milenio," onu.org.mx, [online]. Disponible en https://www.onu.org.mx/ agenda-2030/objetivos-de-desarrollo-del-milenio/

[2] Vallejo G, Higgins M, Escobar E., "Tras El Acuerdo De París," DYNA Ing Ind, vol. 92, pp. 12-94, Jan. 2017. Disponible en https://recyt.fecyt.es/index.php/DY/article/view/54586

[3] J. G. Rueda-Bayona, A. Guzmán, J. J. C. Eras, R. Silva-Casarín, E. Bastidas-Arteaga \& J. HorrilloCaraballo, "Colombia and the opportunity for the offshore wind technology," J Clean Prod, vol. 220, pp. 529-543, 20 May. 2019. https://doi.org/10.1016/j.jclepro.2019.02.174

[4] S. Burch, "In pursuit of resilient, low carbon communities: An examination of barriers to action in three Canadian cities," En Pol, vol. 38, no. 12, pp. 7575-7585, Dec. 2010. https://doi.org/10.1016/j.enpol.2009.06.070

[5] G. Resch, C. Panzer \& A. Ortner, "2030 RES targets for Europe," presented at European Intelligent Energy Europe project, KEEPONTRACK, VIE, AT, 2014. Available from https://keepontrack.eu/contents/publicationsscenarioreport/kot--2030-res-targets-for-europe.pdf

[6] World Energy Council, "World Energy Resources 2016," presented at WE Council, WE Council, pp. 6-46, 2016. Available: https://www.worldenergy.org/publications/entry/world-energy-resources-2016

[7] J. R. Quintero \& L. E. Quintero, "Energía mareomotriz potencial energético y medio ambienteGest Ambient , vol. 18, no. 2, pp. 121-134, 2015. Available: https://revistas.unal.edu.co/index.php/gestion/article/ view/46511/54414

[8] A. Vaughan, "Swansea tidal lagoon plan revived without government funding," The Guardian, [online], 2019. Available: https://www.theguardian.com/environment/2019/feb/04/swansea-tidal-lagoon-plan-government

[9] D. Magagna \& A. Uihlein, "Ocean energy development in Europe: Current status and future perspectives," IJOME, vol. 11, pp. 84-104, Sep. 2015. https://doi.org/10.1016/j.ijome.2015.05.001

[10] S. P. Neill, A. Angeloudis, P. E. Robins, I. Walkington, S. L. Ward, I. Masters, M. J. Lewis, M. Piano, A. Avdis, M. D. Piggott, G. Aggidis, P. Evans, T. A. A. Adcock, A. Židonis, R. Ahmadian \& R. Falconer, "Tidal range energy resource and optimization - Past perspectives and future challenges," Ren Ene, vol. 127, pp. 763-778, Nov. 2018. https://doi.org/10.1016/j.renene.2018.05.007 
[11] J. J. Cabello, M. Balbis, A. Sagastume, A. Pardo, M. Cabello, F. J. Rey \& J. G. Rueda-Bayona, "A look to the electricity generation from non-conventional renewable energy sources in Colombia," Int J Energy Econ Policy, vol. 9, no. 1, pp. 15-25, 2019. https://doi.org/10.32479/ijeep.7108

[12] J. Polo, J. Rodríguez \& A. Sarmiento, "Tidal Current Potential for Energy Generation along the Colombian Coastline," Rev Ing, no. 28, pp. 99-105, Nov. 2008. https://doi.org/10.16924/revinge.28.13

[13] T. Liu, B. Wang, N. Hirose, T. Yamashiro \& H. Yamada, "High-resolution modeling of the Kuroshio current power south of Japan," J Ocean Eng Mar Energy, vol. 4, pp. 37-55, Feb. 2018. https://doi.org/10.1007/ s40722-017-0103-9

[14] S. Waldman,S. Bastón, R. Nemalidinne, A. Chatzirodou, V. Venugopal \& J. Side, "Implementation of tidal turbines in MIKE 3 and Delft3D models of Pentland Firth \& Orkney Waters," Oce Coa Man, vol. 147, pp. 21-36, 1 Oct. 2017. https://doi.org/10.1016/j.ocecoaman.2017.04.015

[15] Government S, "Energy in Scotland: Get the facts," Mec Voc Educ, vol. 3, pp. 6-8, 2014. Available: https://www.cnki.net/kcms/doi/10.16309/j.cnki.issn.1007-1776.2003.03.004.html

[16] A. Rahman \& V. Venugopal, "Parametric analysis of three dimensional flow models applied to tidal energy sites in Scotland," ECSS, vol. 189, pp. 17-32, 5 Apr. 2017. https://doi.org/10.1016/j.ecss.2017.02.027

[17] J. G. Rueda-Bayona, E. Rodriguez \& J. R. Ortíz, "Caracterización espacio temporal del campo de vientos superficiales del Pacífico colombiano y el Golfo de Panamá a partir de sensores remotos y datos in situ," Boletín Científico CCCP, no. 14, pp. 49-68, Dic. 2007. https://doi.org/10.26640/01213423.14.49_68

[18] NOAA, "NCEP NARRNCEP North American Regional Reanalysis: NARR," NOAA, [online], 2016. Available: https://psl.noaa.gov/data/gridded/data.narr.html

[19] NOAA, "NOAA WAVEWATCH IIIß CFSR Reanalysis Hindcasts," polar.ncep.noaa.gov, [online], 2018. Available: https://polar.ncep.noaa.gov/waves/CFSR_hindcast.shtml

[20] NOAA, "ETOPO1 Global Relief Model," NOAA, [online], 2018. Available: https://www.ngdc.noaa.gov/ $\mathrm{mgg} / \mathrm{global} /$

[21] H. García, R. A. Locarnini, T. P. Boyer \& J. I. Antonov, "World Ocean Atlas 2013," vol. 4: Dissolved Inorganic Nutrients (phosphate, nitrate, silicate), SSMD: NODC, Sep. 2013. Available: https://repository. library.noaa.gov/view/noaa/14850

[22] I. G. Bryden, T. Grinsted \& G. T. Melville, "Assessing the potential of a simple tidal channel to deliver useful energy," APOR, vol. 26, no. 5, pp. 198-204, Jul. 2004. https://doi.org/10.1016/j.apor.2005.04.001

[23] C. Andrade, O. Rangel \& É. Herrera, “,” Atlas de los Datos Oceanográficos de Colombia 1922-2013 Temperatura, Salinidad, Densidad, Velocidad Geostrófica, Bog. Col.: DIMAR, ECOPETROL, 2015. https:// doi.org/10.26640/9789585897809.2015

[24] V. Castillo-Jiménez, J. Valle-Hernández \& D. Fuentes-Hernández, "Diseño de una turbina para corrientes marinas [Sea current turbine design]," Ing Tec Cienc Apl, vol. 1, pp. 32-36, 2016. Available: https:// xdoc.mx/preview/diseo-de-una-turbina-para-corrientes-marinas-sea-current-turbine-5edd4d9493e9a

[25] S. H. E. A. Aleem, A. F. Zobaa \& A. M. Ibrahim, "Mathematical Analysis of the Turbine Coefficient of Performance for Tidal Stream Turbines," presented at Conference: The 16thInternational Middle East Power Systems Conference, MEPCON'14, CA, EG, 2014. Available from https://bura.brunel.ac.uk/bitstream/2438/11044/1/Fulltext.pdf

[26] Deltares Systems, "Delft3D-FLOW Simulation of multi-dimensional hydrodynamic flows and transport phenomena, including sediments," User Manual 2014, NL: DELTARES, 2014. Available: https://oss.deltares.nl/documents/183920/185723/Delft3D-FLOW_User_Manual.pdf

[27] D. S. Van Maren \& H. Gerritsen, "Residual flow and tidal asymmetry in the Singapore Strait, with implications for resuspension and residual transport of sediment," J Geophys Res Ocean, vol. 117, pp. 1-18, 2012. https://doi.org/10.1029/2011JC007615 